University of Nebraska - Lincoln

DigitalCommons@University of Nebraska - Lincoln

1988

\title{
Native American Plant Hosts of Asphondylia websteri (Diptera: Cecidomyiidae)
}

\author{
Raymond J. Gagne \\ Systematic Entomology Laboratory, BBII, USDA-ARS \\ William M. Woods \\ Western Australia Department of Agriculture, 3 Jarrah Road West, South Perth 6151, Western Australia, \\ Australia
}

Follow this and additional works at: https://digitalcommons.unl.edu/systentomologyusda

Part of the Entomology Commons

Gagne, Raymond J. and Woods, William M., "Native American Plant Hosts of Asphondylia websteri (Diptera: Cecidomyiidae)" (1988). USDA Systematic Entomology Laboratory. 16.

https://digitalcommons.unl.edu/systentomologyusda/16

This Article is brought to you for free and open access by the Entomology Collections, Miscellaneous at DigitalCommons@University of Nebraska - Lincoln. It has been accepted for inclusion in USDA Systematic Entomology Laboratory by an authorized administrator of DigitalCommons@University of Nebraska - Lincoln. 


\title{
Native American Plant Hosts of Asphondylia websteri (Diptera: Cecidomyiidae)
}

\author{
RAYMOND J. GAGNE' AND WILLIAM M. WOODS ${ }^{2}$
}

\begin{abstract}
Ann. Entomol. Soc. Am. 81(3): 447-448 (1988)
ABSTRACT Asphondylia websteri Felt is reported for the first time from native American hosts, Parkinsonia and jojoba. Previously, this apparently native American gall midge was known only from alfalfa and guar, two species exotic to North America. Such a wide disparity of hosts is otherwise unknown for North American Asphondylia spp. This discovery excludes A. websteri from consideration as a biocontrol agent of Parkinsonia aculeata in Australia.
\end{abstract}

KEY WORDS Insecta, galls, biocontrol, parasite

Asphondylia websteri Felt, until now known only from exotic plant hosts in the southwestern United States, is apparently a native American insect Gagné \& Wuensche 1986). The only previously known hosts were two fabaceous plants purposely introduced into North America. These were alfalfa Medicago sativa L.) in Arizona and New Mexico and guar (Cyamopsis tetragonoloba (L.) Taubert) in Texas, Oklahoma, northern Mexico, and Arizona Rogers 1972, Gagné \& Wuensche 1986). The gall midge lays eggs in the ovaries of flowers. The galls that result from larval feeding prevent the normal development of the ovaries or seeds. True to the prediction that this species would eventually be found on native plants (Gagné \& Wuensche 1986), the insect has recently been discovered on two native American host genera. One is Parkinsonia, another fabaceous plant but belonging to a tribe different from guar and alfalfa. The other host, jojoba (Simmondsia chinensis (Link) C. Schneider) belongs to a separate family, Simmondsiaceae.

Parkinsonia aculeata L. (Mexican palo verde, retama, retaima, Jerusalem thorn) is an introduced weed in northern Australia, where it grows in dense thickets along riverbanks and low-lying areas. It shades out desirable native vegetation and prevents cattle gaining access to waterholes. Because of its spines, the plant also makes herding cattle more difficult. In 1983 the states of Queensland, Northern Territory, and Western Australia embarked on a joint biological control program against this weed While searching for natural enemies of the plant in Arizona and Mexico in 1985 , one of us (W.W.) discovered damage to flowers of Parkinsonia spp. aused by an Asphondylia that we later determined as A. websteri. Adult A. websteri emerged from 25 of 100 flower buds of $P$. aculeat a collected on 21 August at Tucson, Ariz., and 11 and 10 adults emerged, respectively, from 100 galls collected at sasabe, Ariz., on 29 May and 24 August. Dissection

${ }^{1}$ Systematic Entomology Laboratory, BBII, USDA-ARS, c/ L.S Vational Museum, NHB 168, Washington, D.C. 20560

${ }^{2}$ Western Australia Department of Agriculture, 3 Jarrah Road Vest. South Perth 6151. Western Australia, Australia. of 50 flower buds collected on 31 August in Tucson showed 26 infested with A. websteri larvae. Pods of $P$. aculeata were also attacked, and adult gall midges were reared from pods of Parkinsonia microphylla Torrey (foothills palo verde) and flowers of Parkinsonia florida (Bentham ex Gray) S. Watson (blue palo verde).

Widely planted as an ornamental in the southwestern United States, $P$. aculeata flowers throughout the year whenever soil water is available and air temperature is not too low. In Tucson, the plant has a large flush of flowers in spring and summer, but occasional trees flower in all other months, with the possible exception of January and February. W.W. reared adult websteri from fresh galls there every month from May to December. Infested flowers remain unopened and eventually abort. Inside the flower the fully developed stamens and pistil remain encapsulated and appear healthy but in a state of suspended animation during the life of the larva, which grows in a savity lined with a fungus on which the larva apparently feeds. Pupation occurs in the cavity. The flower or pod dies after the pupa cuts its way to the exterior and the adult escapes. Usually one larva develops in a flower, but occasionally there are two or three larvae, each in a separate cavity. Only one larva develops in a pod gall.

Parasitism of the Asphondylia by Hymenoptera is heavy. Torymus capillaceus (Huber) (Torymidae), Galeopsomyia sp. (Eulophidae), and Pseudocatolaccus quizoti Girault (Pteromalidae) were reared from flower galls on $P$. aculeata. In addition, a eulophid wasp, Tetrastichus sp., was a common inhabitant of A. websteri galls. This species formed its own spherical "endogalls" within Asphondylia galls, similar to those reported for Tetrastichus cecidobroter Gordh \& Hawkins on Atriplex (Hawkins \& Goeden 1982). One to several of these endogalls occur in some flowers infested by $A$. websteri and severely constrict the cecidomyiid cavity, killing the larva inside

Parkinsonia belongs to the fabaceous subfamily Caesalpinioideae (Polhill \& Raven 1978). Alfalfa 
and guar, the introduced hosts of the gall midge, not only are in a different subfamily, the Papilionoideae, but are themselves in very different groups: alfalfa belongs to the tribe Trifolieae and guar to the Indigofereae, both in the subfamily Papilionoideae. That the insect attacks such widely different hosts within a family is surprising, because most species of Asphondylia are known to be closely host specific and shown to be distinct (Möhn 1959, Hawkins et al. 1986), and distinct sections of Asphondylia occur on monophyletic plant groups (Gagné 1978). But Orphanides (1975) claimed a wide host range for Asphondylia gennadii (Marchal) or a group of very similar sibling species on Cyprus. Asphondylia gennadii that emerged from pods of carob, Ceratonia siliqua L. (Fabaceae), and were then caged with hosts belonging to several different families, oviposited on some of those plants, and their larvae developed successfully. It is not known whether this happens under natural conditions with $A$. gennadii, although a Japanese Asphondylia sp. does appear indistinguishable or nearly so in all stages (Yukawa 1980). Asphondylia sp. on soybean cannot overwinter on that plant because the host dies back in winter in Japan; whether the soybean species overwinters on another legume or, as seems likely, another host, is under investigation (Yukawa et al. 1986).

At least $A$. websteri has hosts on unrelated groups of plants. Not only does websteri occur on separate tribes of Fabaceae, it is found also on jojoba, $S$. chinensis. Jojoba is a native Sonoran Desert plant that in recent years has become increasingly commercialized for the liquid wax in its seeds (Pinto \& Frommer 1980). Asphondylia websteri was collected from fruit of jojoba as early as 1976 and was found many times subsequently in southern California, Arizona, and Baja California (Pinto \& Frommer 1980, as Asphondylia sp. n.). In addition to those plants, A. websteri must have yet other native hosts, because Parkinsonia and jojoba do not occur in Oklahoma where Rogers (1972) found this species on guar.

Larvae, pupae, and both sexes of the Asphondylia from Parkinsonia and jojoba are identical according to the characters outlined in Gagné \& Wuensche (1986). Two species sharing such losses in adult and larval character states and adaptations of the pupa must be at least closely related. If the Asphondylia on Parkinsonia is not A. websteri but a sibling species instead (no host transfer studies have been done, and there are no plans to do any in the near future), it is still striking that such similar forms occur on relatively distant taxa as various legumes and jojoba. Introduction of A. websteri into Australia for the control of Parkinsonia is certainly inadvisable if there is a chance it would attack alfalfa and other important crops.

Another species of Cecidomyiidae, Contarinia texana (Felt), also occurs on both guar and Parkinsonia; Woods found it in pods and flowers of Parkinsonia spp. It was previously known only from pods and flowers of guar in Oklahoma and Texas (Rogers 1972). Whatever attraction the two hosts have for $C$. texana may also draw $A$. websteri. Contarinia texana may have additional native hosts, also, because Parkinsonia does not naturally occur in Texas and Oklahoma where texana was reported by Rogers (1972).

Voucher specimens of all stages of A. websteri from Parkinsonia spp. are in the U.S. National Museum of Natural History (NMNH) in Washington, D.C.; those from jojoba are in the NMNH and in the entomology collection of the University of California at Riverside.

\section{Acknowledgment}

We thank Saul I. Frommer, David A. Nickle, R. V. Peterson, Charlie Rogers, and J. Yukawa for their helpful comments on a draft of the manuscript.

\section{References Cited}

Gagne, R. J. 1978. A new species of Asphondylia (Diptera: Cecidomyiidae) from Costa Rica with taxonomic notes on related species. Proc. Entomol. Soc. Wash. 80: 514-516.

Gagné, R. J. \& A. L. Wuensche. 1986. Identity of the Asphondylia (Diptera: Cecidomyiidae) on guar, $\mathrm{Cy}$ amopsis tetragonoloba (Fabaceae), in the southwestern United States. Ann. Entomol. Soc. Am. 79: 246250.

Hawkins, B. A. \& R. D. Goeden. 1982. Biology of a gall-forming Tetrastichus (Hymenoptera: Eulophidae) associated with gall midges on saltbush in southern California. Ann. Entomol. Soc. Am. 75; 444-447.

Hawkins, B. A., R. D. Goeden \& R. J. Gagné. 1986. Ecology and taxonomy of the Asphondylia spp. (Diptera: Cecidomyiidae) forming galls on Atriplex spp. (Chenopodiaceae) in southern California. Entomography $4: 55-107$.

Möhn, E. 1959. Gallmücken (Diptera, Itonididae) aus El Salvador. 1 Teil. Senckenb. Biol. 40: 297-368.

Orphanides, G. M. 1975. Biology of the carob midge complex, Asphondylia spp. (Diptera, Cecidomyiidae), in Cyprus. Bull. Entomol. Res. 65: 381-390.

Pinto, J. D. \& S. I. Frommer. 1980. A survey of the arthropods on jojoba (Simmondsia chinensis). Environ. Entomol. 9: 137-143.

Polhill, R. \& P. Raven [eds.]. 1978. Advances in legume systematics. Parts 1 and 2. International Legume Conference. Kew, London.

Rogers, C. E. 1972. Midges associated with guar in Texas and Oklahoma. J. Econ. Entomol. 65: 12041208.

Yukawa, J. 1980. Life histories and host plants of the genus Asphondylia (Diptera: Cecidomyiidae) in Japan. Proc. Assoc. Plant Prot. Kyushu 26: 125-127.

Yukawa, J., A. Nakawatase \& M. Horikiri. 1986. Age structure and survival rate of the soybean pod gall midge, Asphondylia sp. (Diptera: Cecidomyiidae) occurring on soybean cultivated in early winter. Proc. Assoc. Plant Prot. Kyushu 32: 127-129.

Received for publication 11 August 1987; accepted 10 December 1987. 